\title{
The Impact of Exports on Productivity: Evidence from China's Machinery Manufacturing Firms
}

\author{
Ling-Ju YAN ${ }^{1, a,{ }^{*}}$ \\ ${ }^{1}$ Business School, East China University of Political Science and Law, Shanghai, China, 201620 \\ ayanlingju25@163.com \\ ${ }^{*}$ Corresponding author
}

Keywords: Export, Productivity, A panel data.

\begin{abstract}
The relationship between export and economic growth is one of the key problems in international trade research. The economists focus on how export impacts economic growth recently. Many developed and developing countries' firms and plants have been most extensively studied. However, Chinese firms or plants have not been studied yet. Based on a panel data, we utilize the basic model and improved model to make an overall analysis on the efficiency of China's machinery manufacturing industry. We find that self-selection effect is positive and statistically significant, while learning-by-exporting effect is not significant and the productivity advantage enjoyed by China is static and no productivity growth advantage is found.
\end{abstract}

\section{Introduction}

The relationship between export and economic growth is one of the key problems in international trade research, and economists focus on how export impacts economic growth recently. Export changes factor productivity through: (1) improving production technology; (2) expanding the scope of productive industry; (3) boosting productive firms' market share. Existing research mostly focus on technical changes on macro level and industrial level.

Since the benefits of exporting for firm do exist but are harder to locate (Bernard, Jensen 1999), little was known about the characteristics of firms that export and the research on it does not extents to plant level until mid 1990s. Bernard and Jensen (1995) have pioneered a new literature on the micro-econometrics of firm characteristics, exporting, and productivity, and there is now evidence on the relationship for a number (but still a small number) of countries using a range of investigative methods (Girma, Greenaway and Kneller, 2004). The literature on self-selection hypothesize that exporting plants are more efficient than their domestically oriented counterparts, and literature on learning-by-exporting hypothesize that firms learn to be more efficient by becoming exporters. An exporter may increase its productivity after it enters export markets. Empirical studies on many developed and developing countries' firms and plants often find evidence to support these hypothesis. Bernard and Jensen (1995, 1999), Richardson and Rindal (1995) investigate US firms, Bernard and Wagner (1997), Bernard et al. (1997) study Germany firms, Girma and Kneller (2003) find that among English firms, the better ones tend to export. Aw and Hwang (1995)survey Chinese firms in Taiwan and conclude that the exporting companies produce more products, have more employees, pay more and have higher productivity. Sjoholm (1997) investigate Indonesian firms and all find that exporting firms become more productive after export and firms' export/product ratio is positive with productivity growth. However, Chinese firms or plants have not been studied yet except Kraay (1999), Aw and Hwang (1995).

In sum, the literature consistently finds evidence to support that exporting firms in developed countries are generally more productive than non-exporting firms, but they do not become more productive after export. However, exporting firms in developing countries are generally become more productive after export, but no more productive than non-exporting firms, and little is known about Chinese firm. In this paper, we analyze the interaction between exporting and firm performance in China. To set appropriate policy, we need to understand how Chinese plants become exporters and what happen to them after they enter the export markets. So our analysis is centered on two key 
questions: do Chinese firms with high productivity become exporters and do exporting plants become more productive after export?

To answer the above questions, this paper is organized as following. First, in section 2, we discuss the model used in the paper. Then, we examine whether good plants become exporters in China, and whether exporting plants are superior to those which never export in section 3. Section 4 concludes.

\section{Theory and Hypotheses}

To answer the first question, we utilize the expand model on the base of Bernard and Jensen's model. Since workers at different levels of skill contribute differently to plants performance, we distinguish between skilled workers from unskilled workers. Bernard and Jensen do not distinguish the contribution made by skilled labors from the unskilled. For export are quiet different regionally in China, we take area into consideration. The estimated models are

$$
\begin{aligned}
& \ln X_{i t}=\alpha+\beta \text { Export }_{i t}+\theta_{e m} \ln E M_{i t}+\theta_{s} \ln S_{i t}+\theta_{u} \ln U_{i t}+\lambda \text { Area }_{i}+\varepsilon_{i t} \\
& \ln X_{i 0}=\alpha+\beta \text { Export }_{i 0}+\theta_{e m} \ln E M_{i 0}+\theta_{s} \ln S_{i 0}+\theta_{u} \ln U_{i 0}+\lambda \text { Area }_{i}+\varepsilon_{i 0} \\
& \% \Delta X_{i T}=\frac{\ln X_{i T}-\ln X_{i 0}}{T}=\alpha+\beta \text { Export }_{i T}+\theta_{e m} \ln E M_{i 0}+\theta_{s} \ln S_{i 0}+\theta_{u} \ln U_{i 0}+\lambda \text { Area }_{i}+\varepsilon_{i}
\end{aligned}
$$

Where $\mathrm{Xi}$ is the every characteristic for plant $\mathrm{i}$, such as total employment, value-added per worker, total factor productivity (TFP). Exportit is a dummy for export status in the year $\mathrm{t}$, and Areai is a dummy for the area where plant i locates. Si and Ui are the numbers of skilled worker and unskilled worker of planti.

The second question points to the role of learning-by-exporting hypothesis. Knowledge flows from foreign customs and competitors help to improve the post-entry performance of exporter starters.

$$
\% \Delta X_{i T}=\alpha+\beta_{1} \text { Start }_{i T}+\beta_{2} \text { Both }_{i T}+\beta_{3} \text { Stop }_{i T}+\lambda \text { Area }_{i}+\gamma \ln Y_{i 0}+\varepsilon_{i}
$$

Where Start $_{i T}=1$ if Export $_{i 0}=0$ and, i.e., plant i does not export at base period and exports in the year of T; Both $_{i T}=1$ if Export $_{i 0}=1$ and, i.e., plant i exports both at base period and in the year of T; Stop $_{i T}=1$ if Export $_{i 0}=1$ and Export $_{i T}=0$, i.e., plant $\mathrm{i}$ exports at base period and quit from international market in the year of $\mathrm{T}$.

\section{Methodology}

\section{Sample and Data Collection}

The data for this paper come from annual reports of China's public machinery manufacturing enterprises'. Since machinery manufacturing industry is the first big exporting industry in China, we choose our sample in this industry. And also because plant level data is limited, we select the listed enterprises. The time span is from the year of 1999 to 2007 . We refer to methodology of Bernard and Jensen $(1995,1999)$ and adapt items on plant production, capital invested, skilled workers and unskilled workers to measure characteristics of plants.

\section{Measures}

The plant production is calculated by plants' core operation income minus operation cost including purchasing goods and labor costs at constant price. Skilled workers refer to administrative staffs, engineers, salesmen, finance personnel and other non-production workers. However, the information 
about these staffs is not available, we use education background instead. The skilled people are employees with college degree or above; and the unskilled people are employees without a degree. TFP is calculated as follows, first estimate the coefficient of a Cobb-Douglas specification of value added on capital and labor, then calculate the plant level residual using these coefficients. The plant level measure of TFP is measured as the residual.

\section{Empirical Results}

\section{Assessment of the Measures}

Table 1 presents the difference between exporters and non-exporters. The estimated coefficients are estimated from the regression of the equation (3). Columns a and $b$ report the export premia of all plants and plants in east China. The export premia are positive and significant for total employment, value-added per capita and capital per capita in all years. However, TFP is negative and not significant. The largest differences are found in total employment and value-added per capita, especially for plants in east China. As far as plants located in east China are concerned, total employment ranges from $24 \%$ to $76 \%$, labor productivity premia ranges from $35 \%$ to $65 \%$, while capital intensity ranges from $1 \%$ to $37 \%$. We find that employment's role is growing while value-added per capita is decreasing. We also find that capital only works during the first period. The results support that employment difference are substantial between exporters and non-exporters. The staff size is bigger at exporters, while value-added per capita difference is decreasing.

Table1 Exporter premia

\begin{tabular}{|c|c|c|c|c|c|c|}
\hline & \multicolumn{2}{|c|}{$1999-2001$} & \multicolumn{2}{|c|}{$2002-2004$} & \multicolumn{2}{|c|}{$2005-2007$} \\
\hline & All plants & $\begin{array}{c}\mathrm{b} \\
\text { Plants in } \\
\text { East } \\
\text { China }\end{array}$ & All plants & $\begin{array}{c}\mathrm{b} \\
\text { Plants in } \\
\text { East } \\
\text { China }\end{array}$ & All plants & $\begin{array}{c}\mathrm{b} \\
\text { Plants in } \\
\text { East } \\
\text { China }\end{array}$ \\
\hline Total employment & $0.353109^{* * * *}$ & $0.386624^{* * *}$ & $0.241676^{* *}$ & $0.405784^{* * * *}$ & $0.584707^{\text {*** }}$ & $0.766332^{* * * *}$ \\
\hline $\begin{array}{l}\text { Value-added per } \\
\text { capita }\end{array}$ & $0.653952^{\text {**** }}$ & $0.577585^{* * *}$ & $0.598926^{* * *}$ & $0.458653^{* * *}$ & $0.508883^{* * *}$ & $0.354898^{* *}$ \\
\hline TFP & 0.027858 & 0.072863 & 0.070371 & 0.11793 & -0.453562 & -0.423558 \\
\hline Capital per capita & $0.376711^{* * * *}$ & $0.305955^{* *}$ & 0.288427 & 0.186781 & 0.134308 & 0.011274 \\
\hline
\end{tabular}
$* * * \mathrm{p}<0.01 ; * \mathrm{p}<0.05 ; * \mathrm{p}<0$.

Table 2 ex-ante superiority in different areas

\begin{tabular}{|c|c|c|c|c|c|}
\hline & & All plants & $\begin{array}{l}\text { Plants in } \\
\text { East China }\end{array}$ & All plants ${ }^{\mathrm{a}}$ & $\begin{array}{c}\text { Plants in } \\
\text { East China }^{\mathrm{b}}\end{array}$ \\
\hline \multirow{4}{*}{ 1999-2001 } & Total employment & $0.982543^{* * * * *}$ & $0.918111^{\text {***** }}$ & - & - \\
\hline & $\begin{array}{l}\text { Value-added per } \\
\text { capita }\end{array}$ & 0.46334 & 0.341795 & $0.863488^{* * *}$ & $0.771358^{* *}$ \\
\hline & TFP & $0.45662^{* * *}$ & $0.436149^{*}$ & $0.482723^{* *}$ & $0.461816^{*}$ \\
\hline & Capital per capita & 0.113833 & -0.036545 & $0.619718^{* *}$ & $0.47949^{*}$ \\
\hline \multirow{4}{*}{ 2002-2004 } & Total employment & 0.124654 & 0.205226 & - & - \\
\hline & $\begin{array}{l}\text { Value-added per } \\
\text { capita }\end{array}$ & $0.674199^{* * *}$ & 0.205226 & $0.70139^{* * *}$ & $0.603799^{* * *}$ \\
\hline & TFP & $0.40249^{* *}$ & $0.347717^{* *}$ & $0.40589^{* *}$ & $0.350648^{* *}$ \\
\hline & Capital per capita & $0.471201^{* *}$ & $0.404229^{*}$ & $0.526512^{* * *}$ & $0.477191^{* *}$ \\
\hline \multirow{4}{*}{ 2005-2007 } & Total employment & $0.639571^{* * *}$ & $0.761733^{* * *}$ & 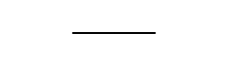 & - \\
\hline & $\begin{array}{l}\text { Value-added per } \\
\text { capita }\end{array}$ & $0.613414^{* *}$ & $0.488404^{*}$ & $0.75313^{* * *}$ & $0.711922^{* * *}$ \\
\hline & TFP & $0.496613^{\text {*** }}$ & $0.462291^{* * *}$ & $0.544824^{* * *}$ & $0.503861^{* * *}$ \\
\hline & Capital per capita & -0.091369 & -0.177753 & 0.229942 & 0.23066 \\
\hline
\end{tabular}

$* * * \mathrm{p}<0.01 ; * \mathrm{p}<0.05 ; * \mathrm{p}<0$. Columns a and $\mathrm{b}$ classify different labors as skilled and unskilled. 
To compare plants productivity before starting export and after, we choose plants that did not export in base period, and then classify them by the end of the period. Table 2 above reports the regression results on the difference in base period between future exporters and non-exporters. The total employments of the future exporters are significantly larger than that of non-exporters. We control for plants scale and different types of labor, and then we find the premia of labor productivity is significantly high. The results show that future exporters have superior characteristics before beginning to exporting relative to non-exporters.

On the base of the upper statistic analysis, we find that in Chinese machinery industry exporters have the advantages of employment scale, labor productivity and capital intensity. These results provide evident supports for the hypothesis that good plant becomes exporter. And the performance of these plants in foreign markets can be measured by the variation of employment scale, labor productivity, TFP and capital intensity.

Table 3 export premia of non-exporters in initial period

\begin{tabular}{cccccc}
\hline & All plants & $\begin{array}{c}\text { Plants in } \\
\text { East China }\end{array}$ & All plants $^{\mathrm{a}}$ & $\begin{array}{c}\text { Plants in } \\
\text { East China }^{\mathrm{b}}\end{array}$ \\
\hline \multirow{3}{*}{$1999-2001$} & Total employment & 0.0756 & 0.0557 & - & - \\
& Value-added per & -0.1283 & -0.1142 & $-0.1838^{*}$ & $-0.1920^{*}$ \\
& capita & -0.0779 & -0.0897 & $-0.1838^{*}$ & -0.1030 \\
& TFP & -0.1576 & -0.1134 & -0.2132 & -0.1926 \\
& Capital per capita & -0.0128 & 0.1528 & - & - \\
& Total employment & -0.0334 \\
& Value-added per & -0.0128 & -0.0577 & 0.0072 & -0.0334 \\
& capita & -0.0484 & -0.0464 & -0.0531 & -0.0538 \\
& TFP & -0.0931 & -0.1324 & -0.0803 & -0.1171 \\
& Capital per capita & 0.0678 & 0.0287 & - & - \\
& Total employment & -0.0478 & -0.0478 \\
& Value-added per & -0.1002 & -0.0652 & -0.0778 & -0.1313 \\
capita & TFP & -0.0484 & -0.1374 & -0.1145 & $0.1588^{*}$ \\
\hline
\end{tabular}

$* * * \mathrm{p}<0.01 ; * \mathrm{p}<0.05 ; * \mathrm{p}<0$. Columns a and $\mathrm{b}$ classify different labors as skilled and unskilled.

Table 4 variation of the productivity of the classified exporters

\begin{tabular}{ccccccccc}
\hline & \multicolumn{2}{c}{$1999-2001$} & \multicolumn{2}{c}{$2002-2004$} & \multicolumn{2}{c}{$2005-2007$} & \multicolumn{2}{c}{$1999-2007$} \\
& Start & Both & Start & Both & Start & Both & Start & Both \\
\hline Total & 0.41241 & -0.077 & 0.2697 & 0.0694 & 0.24141 & -0.048 & 0.1285 & 0.0544 \\
employment & & 40 & 4 & 0 & 15 & & 1 \\
Value-added & -0.4127 & 0.0119 & -0.0701 & 0.0200 & -0.2524 & 0.0481 & -0.05742 & 0.0400 \\
per capita & 3 & 4 & 7 & & 7 & 7 \\
TFP & -0.1040 & 0.0469 & -0.0282 & 0.0263 & -0.2329 & -0.052 & 0.05702 & 0.0496 \\
& 3 & 3 & 6 & 6 & 68 & 4 \\
Capital per & -0.4542 & -0.092 & -0.1192 & -0.050 & 0.05740 & 0.1245 & -0.1169 & -0.030 \\
capita & $6^{*}$ & 55 & 7 & 43 & & 0 & & 1 \\
\hline
\end{tabular}

$* * * \mathrm{p}<0.01 ; * \mathrm{p}<0.05 ; * \mathrm{p}<0$.

Table 3reports the export premia of non-exporters in initial period, and it shows that most of the regression coefficients of total employment, value-added per capita, TFP and capital intensity are negative and statistically not significant. This is not consistent with the mainstream view which holds that the productivity growth of future exporters is higher than that of non-exporters. This paper discovers that there exists self-selection effect in Chinese listed machinery plants. The exporters have superior characteristics, including employment scale, productivity and capital intensity; and the future exporters also have significant advantages over non-exporters. For all this, we find no growth 
advantages of exporters over non-exporters. This may lead to a question that do exporters outperform non-exporters?

To examine whether there is a learning-by-exporting for Chinese listed machinery enterprises, we need to know further about these enterprises. We classify plants into the entrants which are non-exporters in the initial year, the dropouts which export in initial year and draw back in the last year, and exporter which keep exporting during the observation period. We utilize the equation (4) to estimate the exporter premia. The results show that most of the estimated coefficients are negative. That shows that there is no learning-by-exporting effect in Chinese listed machinery enterprises.

\section{Conclusion}

This paper uses the panel data of Chinese first larger exporter industry to test self-selection effect and learning-by-exporting effect. Quite different from existing researches which argue that there is self-selection effect in both developed countries and developing countries, and only find learning-by-exporting effect in developing countries, this article finds that self-selection effect is static and learning-by-exporting effect does not exist in Chinese machinery enterprises. For the largest export industry, Chinese listed machinery enterprises export most of their commodities to markets in Latin America, Africa and Middle East. Since the markets in these areas rarely require a higher technical level, Chinese enterprises learn nothing by exporting to these markets. This could be the reasons for why there is no learning-by-exporting effect in the sample enterprises. So the commercial policy to promote export to learn from that market should alter to how to promote exporters to export to developed economy.

\section{References}

[1] Aw, Bee Yan and A. R. Hwang, Productivity and the export market: a firm-level analysis, Journal of Development Economics 47 (1995): 313-332.

[2] A., Bernard, J., Bradford, Exporters, jobs, and wages in U.S. manufacturing: 1976-1987, Brooking Papers on Economic Activity: Microeconomics, (1995): 67-119.

[3] A., Bernard, J., Bradford, Exceptional exporter performance: cause, effect, or both? Journal of International Economics 47(1999): 1-25.

[4] B., Andrew, J., Eaton, J. Bradford Jensen and Samuel Kortum, Plants and productivity in international trade, American Economic Review 93 (2003): 1268-1290.

[5] Girma, Sourafel, David Greenaway and Richard Kneller, Export market exit and performance dynamics: a causality analysis of matched firms, Economics Letter 80 (2003): 181-187.

[6] Hahn, Chin Hee, Exporting and performance of plants: Evidence from Korean manufacturing, NBER Working Paper 10208, January.

[7] Kraay, Aart, Exports and economic performance: evidence from a panel of Chinese enterprises, In Mary-Francoise Renard (Ed.), China and its Regions. Economic Growth and Reform in Chinese Provinces. Cheltenham etc.: Elgar (2002): 278-299.

[8] Melitz, Marc J, The Impact of trade on intra-industry re-allocations and aggregate industry productivity, Econometrica 71 (2002):1695-1725.

[9] The World Bank Development Research Group Trade Team, Exports and Productivity -Comparable Evidence for 14 Countries, The World Bank Policy Research Working Paper 4418, 2007.

[10] The International Study Group on Exports and Productivity: Exports and Productivity: Comparable Evidence for 14 countries, the World Bank Policy Research Working Paper 4418. 